\title{
Klasifikasi Kunci Gitar Menggunakan Spectral Analysis dan K-Nearest Neighbor
}

\author{
Ketut Sulya Arya Wasika, I Ketut Gede Darma Putra, Desy Purnami Singgih Putri \\ Program Studi Teknologi Informasi, Fakultas Teknik, Universitas Udayana \\ Bukit Jimbaran, Bali, Indonesia Telp. (0361) 701806 \\ e-mail: sulyawasika@gmai.com, ikgdarmaputra@unud.ac.id, desysinggihputri@gmail.com
}

\begin{abstract}
Abstrak
Klasifikasi kunci gitar merupakan suatu bentuk klasifikasi guna melakukan pengenalan pada kunci gitar dengan menggunakan hasil rekaman file suara gitar dengan format mono.wav. Proses pengenalan dilakukan karena pendengaran manusia umumnya memiliki kepekaan yang beragam untuk dapat mendengar dan mengenali kunci gitar, sebagai orang awam yang belum terbiasa memainkan alat musik biasanya kebingungan untuk mengenali jenis kunci gitar. Metode Spectral Analysis dan Metode K-Nearest Neighbor (KNN) digunakan untuk mengetahui seberapa efektif proses pengenalan dan pengklasifikasian kunci gitar. Metode Spectral Analysis merupakan metode yang digunakan untuk mendapatkan fitur yang ada pada sebuah kunci gitar yang terdiri dari 5 fitur yaitu Spectral Kurtosis, Spectral Centroid, Spectral Skewness, Spectral Slope, dan Spectral Rolloff. Kelima fitur Spectral kemudian digunakan dalam proses pengenalan menggunakan metode K-NN. Pengujian sistem dengan chord standar menghasilkan tingkat akurasi yang paling tinggi yaitu $83 \%$ dan pengujian sistem dengan gitar half size menghasilkan tingkat akurasi yang paling rendah yaitu $23 \%$.
\end{abstract}

Kata Kunci: K-Nearest Neighbor (K-NN), Spectral Analysis, Kunci gitar

\begin{abstract}
Guitar chord classification is a form classification that is used to identify guitar chord by using recordings of guitar sound files in mono.wav format. The identification process was conducted because human generally has different hearing sensitivity to be able to hear and identify guitar chord. People who are not expert in playing musical instrument tend to be confused to identify the types of guitar chord. Spectral Analysis method and K-Nearest Neighbor method (KNN) was used to find out the effectiveness of identification and classification process of guitar chord. Spectral Analysis method was used to obtain the features in a guitar chord that consist of 5 features, they are Spectral Kurtosis, Spectral Centroid, Spectral Skewness, Spectral Slope, and Spectral Rolloff. Then, the five Spectral features were used in identification process by using KNN method. The result showed that the accuracy rate of system testing with standard chord was the highest, that was $83 \%$ and the accuracy rate of system testing with half size guitar was the lowest, that was $23 \%$.
\end{abstract}

Keywords: K Nearest Neighbor (K-NN), Spectral Analysis, Guitar Chord

\section{Pendahuluan}

Kemampuan mendengar pada manusia digunakan untuk mendengar dan mengenali suara. Manusia mampu mengenali suara karena terjadi proses pembelajaran yang dilakukan secara berulang-ulang. Suara jika dinyanyikan atau dimainkan membentuk sebuah alunan nada yang menghasilkan nilai frekuensi yang berbeda-beda antara nada satu dengan nada lainnya. Menurut teori musik, setiap nada menghasilkan frekuensinya masing-masing [1]. Salah satu alat musik yang umumnya dimainkan yaitu gitar, untuk bisa memainkan gitar diperluakan pemahaman dan penguasaan chord gitar yang benar.

Chord atau biasa juga disebut dengan "Kunci" merupakan gabungan beberapa nada yang dibunyikan secara serentak sehingga menciptakan suara harmonis yang dapat didengar oleh manusia [2]. Chord dapat dimainkan secara terputus-putus maupun secara bersamaan. Pendengaran pada manusia memiliki kepekaan yang beragam untuk mendengar dan mengenali chord gitar [3], seseorang yang terbiasa memainkan alat musik pastinya mampu mengenal jenis 
kunci gitar dan seseorang yang belum terbiasa dapat kesulitan untuk mengenali jenis kunci gitar yang dimainkan.

Penelitian klasifikasi pernah diterapkan sebelumnya untuk prediksi predikat prestasi mahasiswa [4]. Proses prediksi menggunakan metode K-Nearest Neighbor (K-NN). Penggunaan metode KNN untuk prediksi prestasi mahasiswa menggunakan beberapa parameter dalam prosesnya. Parameter yang digunakan yaitu jenis kelamin, umur, jenis tinggal, jumlah nilai mutu (NM), dan jumlah satuan kredit semester (SKS). Proses prediksi dilakukan kepada Mahasiswa angkatan 2014/2015 sebagai data uji dengan jumlah 50 data, serta berdasarkan dari data angkatan 2012/2013 sebagai data training dengan jumlah 165 data. Prediksi prestasi mahasiswa menghasilkan akurasi sebesar $82 \%$. Perbedaan penelitian yang dilakukan dibandingkan dengan penelitian sebelumnya yaitu pada tujuan klasifikasi. Klasifikasi yang dilakukan adalah untuk menentukan chord gitar. Metode penunjang lainnya yang digunakan yaitu metode FFT dan metode Spectral Analysis. Hasil proses Spectral Analysis digunakan untuk menentukan kelas dari sinyal suara yang masuk berdasarkan lima fitur nilai Spectral Analysis, yaitu Spectral Centroid, Spectral Kurtosis, Spectral Slope, Spectral Skewness, dan Spectral Rolloff. Metode KNN berfungsi dalam melakukan identifikasi terhadap objek berdasarkan pada data pembelajaran yang jaraknya paling dekat dengan objek. Penelitian dilakukan guna untuk mengetahui seberapa efektif metode yang digunakan dalam proses pengenalan dan pengklasifikasian chord gitar.

\section{Metodologi Penelitian}

Tahapan-tahapan yang dilakukan dalam penelitian ini dapat dijabarkan dalam alur penelitian yang dapat dilihat pada Gambar 1 .

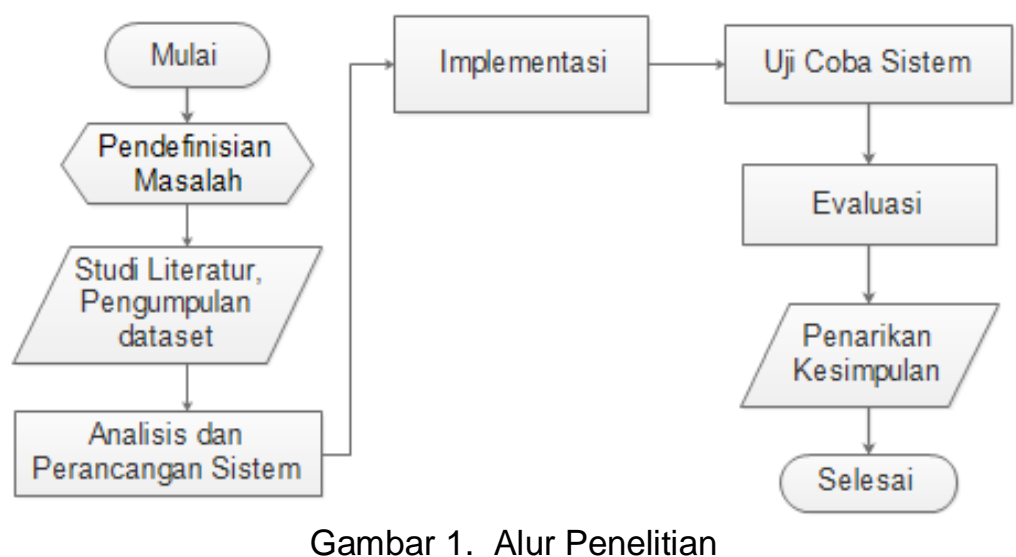

Gambar 1 menjelaskan langkah-langkah Langkah penelitian dimulai dengan pendefinisian masalah dari penelitan klasifikasi kunci gitar. Langkah kedua yaitu studi literatur yang berhubungan dengan klasifikasi, pengumpulan data set yang merupakan data primer yaitu data yang langsung dikumpulkan oleh peneliti dari sumber pertama. Data diperoleh dengan merekam suara dari alat musik gitar data berupa file suara dengan format wav. Langkah ketiga yakni mempelajari dan memahami metode-metode yang digunakan dalam pengklasifikasian guna dapat menganalisis dan merancang sistem menggunakan metode K-Nearest Neighbor. Langkah keempat mengimplementasikan sistem berdasarkan analisis dan perancangan yang telah dilakukan dengan memasukan data set kedalam sistem untuk diklasifikasi menggunakan metode K-NN. Langkah kelima yaitu melakukan uji coba sistem untuk dapat mengetahui tingkat akurasi dan keberhasilan sistem secara keseluruhan. Langkah keenam adalah melakukan evaluasi dari segi akurasi, durasi dan implementasi sistem. Langkah terakhir yaitu mengambil kesimpulan dan memberi saran terhadap perangkat lunak yang telah dibuat.

\subsection{Gambaran Umum Sistem}

Sistem yang dibuat dapat melakukan identifikasi chord pada gitar dan mengetahui tingkat akurasi pada metode KNN. Gambaran umum sistem secara keseluruhan dapat dilihat pada Gambar 2. 


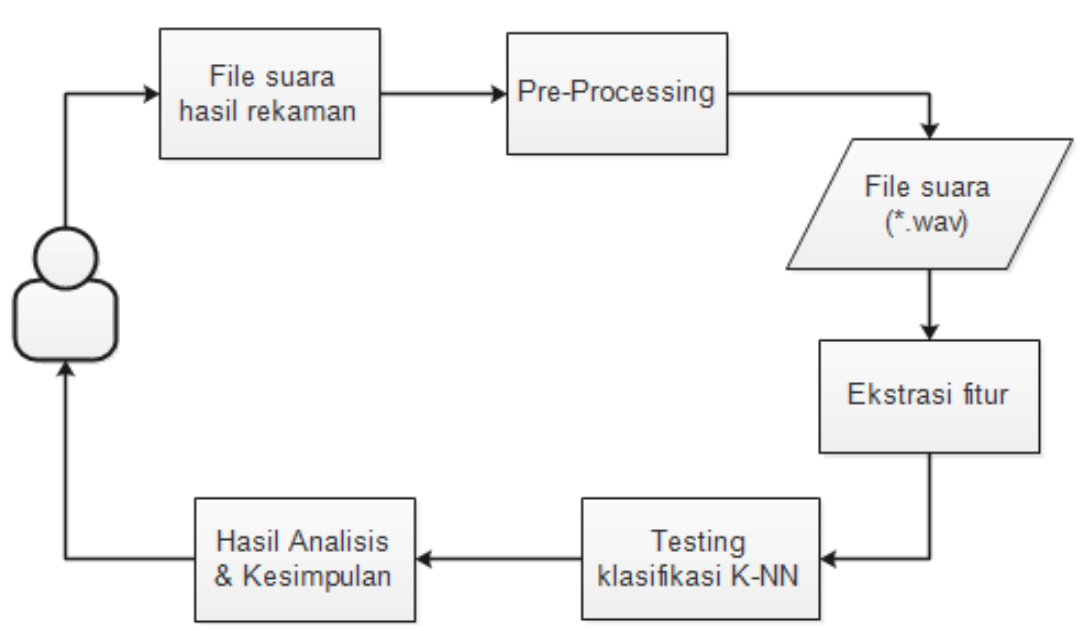

Gambar 2. Gambaran Umum Sistem

Gambar 2 menjelaskan tahapan awal yaitu mengumpulkan data file suara hasil rekaman kemudian melanjutkan pada tahap pre-processing yaitu menyeragamkan durasi dari file suara dan menjadikan format dalam bentuk (*.wav) kemudian tahap Ekstraksi fitur yaitu untuk mendapatkan ciri-ciri khusus pada setiap chord data training. Hasil pada Ekstraksi fitru sebagai dasar data uji untuk proses pengenalan pada Metode K-Nearest Neighbor (K-NN) dan terakhir diuji ketepatan yang dilakukan dengan mengukur akurasinya sehingga mendapatkan hasil analisis dan dapat menarik kesimpulan.

\section{$2.2 \quad$ Ekstraksi Fitur}

Pada tahap ekstraksi fitur, file suara yang di input ( ${ }^{*}$.wav) diproses untuk mendapatkan fitur khusus. Ekstraksi fitur secara keseluruhan dapat dilihat pada Gambar 3.

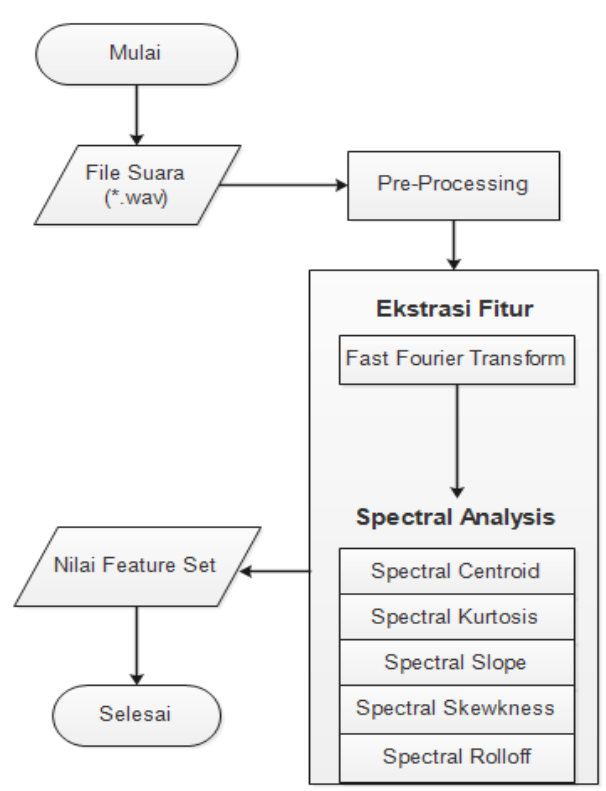

Gambar 3. Proses Ekstraksi Fitur

Gambar 3 memaparkan proses ekstraksi fitur dimana file suara hasil pre-processing dilanjutkan pada proses FFT. Metode FFT digunakan untuk transformasi sinyal suara dalam domain waktu menjadi sinyal dalam domain frekuensi. Hasil yang diperoleh dari Spectral Analysis sebagai metode ekstraksi fitur ini adalah seperangkat nilai atau feature set yang terdiri dari lima atribut data untuk setiap file suara yaitu nilai Spectral Centroid, Spectral Kurtois, Spectral Slope, 
Spectral Skewness, dan Spectral Rolloff. Nilai-nilai fitur selanjutnya dimasukkan ke proses analisis data sebagai nilai masukkan pada pembentukan data uji untuk proses pengenalan.

\section{$3 \quad$ Kajian Pustaka}

Kajian pustaka berupa referensi penunjang yang secara umum digunakan dalam penelitian. Referensi yang dimuat yaitu terkait metode FFT, Spectral Analysis dan metode K-NN.

\subsection{Fast Fourier Transform (FFT)}

Transformasi Fourier digunakan untuk mengubah sinyal dalam domain waktu ke domain frekuensi. Transformasi Fourier dikemukakan oleh Joseph Fourier, merupakan seorang matematikawan Prancis tahun 1822. Pada mulanya penemuan ini dikenal dengan sebutan Fourier Transform (FT) [6]. Fast Fourier Transform adalah metode untuk dapat menghitung koefisien dari Fourier Diskrit ke suatu sekuen terbatas dari data yang kompleks karena substansi waktu tersimpan lebih dari metode konvensional [7]. FFT yaitu salah satu temuan yang penting dalam bidang spektrum analysis, speech and optical signal processing, dan design filter digital. FFT dapat dihitung menggunakan persamaan (1):

$$
X_{n}=\sum_{k=0}^{N-1} x_{k}\left(\cos \left(\frac{2 \pi k n}{N}\right)-j \sin \left(\frac{2 \pi k n}{N}\right)\right)
$$

Keterangan:

$$
\begin{array}{lll}
\mathrm{X} \_\mathrm{n} & = & \text { magnitude frekuensi } \\
\mathbf{X} \mathrm{k} & = & \text { nilai-nilai sampel } \\
\mathrm{N} & = & \text { jumlah sampel pada setiap frame } \\
\mathrm{j} & = & \text { bilangan imajiner }
\end{array}
$$

FFT merupakan salah satu metode yang dapat digunakan untuk melakukan transformasi sinyal suara berupa domain waktu yang menghasilkan sinyal dalam domain frekuensi. Dengan demikian, suara diubah ke bentuk gelombang spektrum suara yang berbasis frekuensi sehingga memudahkan proses analisis spektrum suara

\subsection{Spectral Analysis}

Tahap Spectral Analysis merupakan tahapan dari proses untuk dapat mengambil fitur dari data masukan atau disebut dengan feature extraction. Hasil proses Spectral Analysis akan menentukan kelas dari sinyal suara yang masuk. Dalam penelitian ini digunakan beberapa digital Spectral Analysis.

\subsubsection{Spectral Centroid}

Spectral Centroid adalah titik pusat dari spektrum. Spectral Centroid digunakan untuk dapat menunjukkan tingkat kejernihan suara. Spectral Centoid dapat dihitung dengan menggunakan persamaan (2):

$$
\text { Spectral Centroid }=\frac{\sum_{i=0}^{N F-1} f_{i} P\left(f_{i}\right)}{\sum_{i=0}^{N F-1} P\left(f_{i}\right)}
$$

Variabel $P(f)$ merupakan probabilitas untuk mengamati $f$ yang diambil dari sample (Peeters, 2003)

\subsubsection{Spectral Kurtosis}

Spectral Kurtosis memberikan nilai konsentrasi pada distribusi spektrum suara yang menunjukkan tingkat nada [8]. Spectral Kurtosis dihitung pada iterasi keempat. Spectral Kurtosis, dapat dihitung menggunakan persamaan (3): 


$$
\text { Spectral Kurtosis }=\frac{\sum_{i=0}^{N F-1}\left(P\left(f_{i}\right)-\mu\right)^{4}}{N \sigma^{4}}-3
$$

Variable $\mu$ adalah mean sedangkan variable $\sigma$ merupakan standar deviasi.

\subsubsection{Spectral Slope}

Spectral Slope memberikan indikasi dari jumlah pengurangan amplitude [10]. Spectral Slope dihitung dengan menggunakan persamaan (4):

$$
\text { Spectral Slope }=\frac{1}{\sum_{f} a(k)} \frac{N \sum_{f} f^{2} \cdot A(f)-\sum_{f} f \sum_{f} A(f)}{N \sum_{k} f(k)-\left(\sum_{k} f(k)\right)^{2}}
$$

\subsubsection{Spectral Skewness}

Spectral Skewness memberikan ukuran dari distribusi asimetris dari nilai rata-rata spektrum Fitur, apakah terdapat spektrum yang tendensi (skewed) ke arah kisaran rata-rata nilai aritmatiknya. Spectral Skewness dapat dihitung menggunakan persamaan (5)

$$
\text { Spectral Skewness }=\frac{\sum_{i=0}^{N F-1}\left(P\left(f_{i}\right)-\mu\right)^{3}}{N \sigma^{3}}
$$

\subsubsection{Spectral Rolloff}

Spectral Rolloff adalah frekuensi yang sinyal energinya dibawah 95\% dari normal [9]. Spectral Rolloff didefinisikan sebagai kekuatan Short Time Fourier Transform (STFT). Spectral Rolloff dapat dihitung dengan persamaan (6):

$$
\text { Spectral Rolloff }=\min \left\{f_{i} \mid \sum_{i=0}^{j} P\left(f_{i}\right) \geq R \sum_{i=0}^{N F-1} P\left(f_{i}\right)\right\}
$$

Variable $R$ merupakan total frekuensi rendah yang dimiliki oleh sinyal input.

\subsection{K- Nearest Neighbor (K-NN)}

Algoritma K-Nearest Neighbor (K-NN) merukapn sebuah metode untuk melakukan klasifikasi terhadap objek berdasarkan data pembelajaran yang jaraknya paling dekat [10]. Mendefinisikan jarak antara dua titik yaitu titik pada data sample dan titik pada data uji, maka digunakan rumus Euclidean [11] dengan persamaan (7). KKN dapat dihitung dengan persamaan (7):

$$
d(P, Q)=\sqrt{\sum_{i=0}^{n}(P i-Q i)^{2}}
$$

Keterangan:

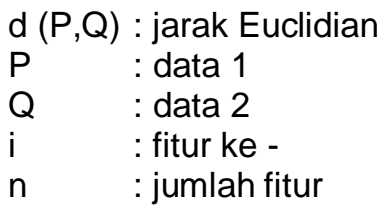




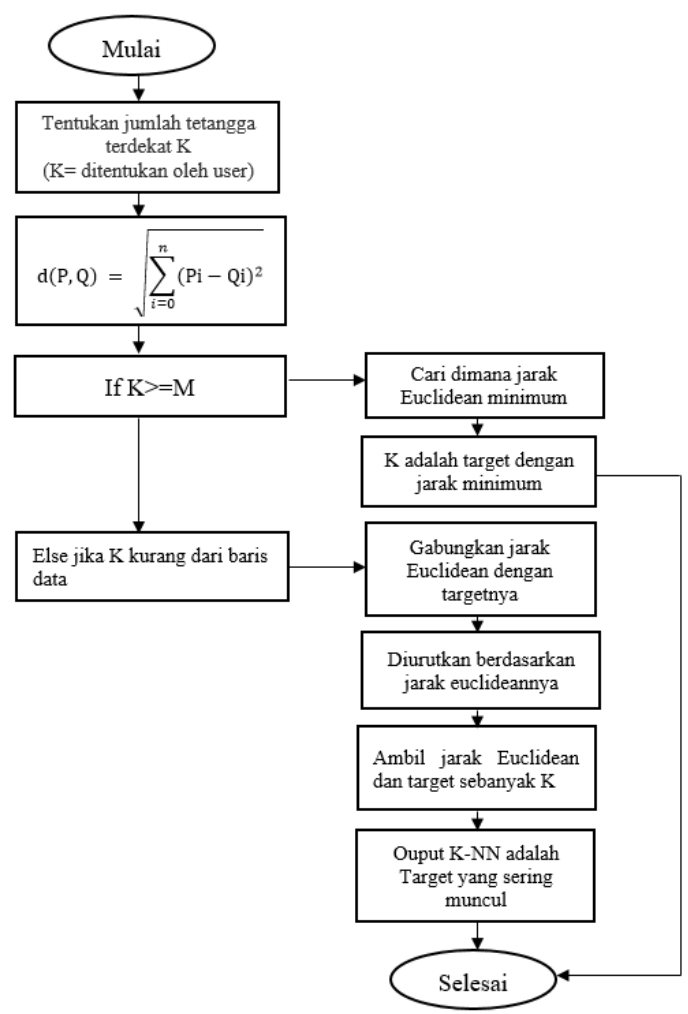

Gambar 5. Algoritma Metode K-NN

Gambar 5 menjelaskan algoritma metode K-NN dimulai dengan membentuk sebuah training dataset atau dataset pelatihan chord gitar yang terbentuk dari file suara chord dengan format ( ${ }^{*}$.wav), kemudian file dalam bentuk sinyal suara dilanjutkan ke proses FFT yaitu proses transformasi menjadi domain frekuensi. File suara hasil proses FFT selanjutnya dilakukan perhitungan nilai fitur dengan menggunakan spectral analysis. Hasil dari tahapan spectral analysis (spectral skewness, spectral centroid, spectral slope, spectral rolloff, dan spectral kurtosis) berupa seperangkat nilai feature set terdiri dari nilai atribut untuk setiap file suara. Menentukan nilai k yang terbaik untuk algoritma tergantung pada data. Secara umum, nilai $k$ yang rendah mampu mengurangi efek noise pada proses klasifikasi.

\section{Hasil dan Pembahasan}

Hasil dan Pembahasan menjelaskan hasil pengujian sistem dengan chord gitar yang secara umum dilakukan dalam penelitian.

\subsection{Sumber Data}

Data yang digunakan dalam penelitian ini terdiri dari tujuh chord mayor yaitu chord a, chord b, chord c, chord d, chord e, chord f, dan chord g. Jumlah data yang dibutuhkan dalam penelitian ini berjumlah 490 data dengan masing-masing chord berjumlah 70 .

Table 1. Data Penelitian

\begin{tabular}{lcc}
\hline Chord & Traning & Testing \\
\hline Chord A & 70 & 10 \\
\hline Chord B & 70 & 10 \\
\hline Chord C & 70 & 10 \\
\hline Chord D & 70 & 10 \\
\hline Chord E & 70 & 10 \\
\hline Chord F & 70 & 10 \\
\hline Chord G & 70 & 10 \\
\hline SUBTOTAL & 490 & 70 \\
\hline TOTAL & \multicolumn{2}{c}{560} \\
\hline
\end{tabular}


Perekaman suara dilakukan menggunakan gitar akustik yang dimainkan dengan teknik strumming. Ilustrasi pengambilan suara gitar dapat dilihat pada Gambar 6 .

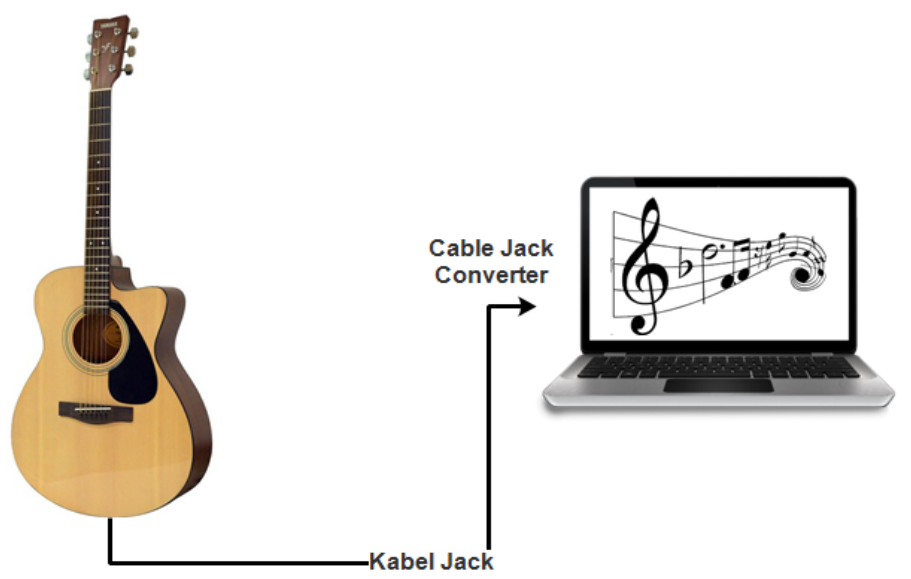

Gambar 6. Ilustrasi Pengambilan Suara Gitar

Gambar 6 menjelaskan mengenai pengambilan data suara. Gitar dihubungkan ke komputer dengan bantuan kabel jack bersama konverternya, untuk mendapatkan kualitas hasil rekaman yang maksimal, perekaman dilakukan pada ruangan yang hening untuk mengurangi noise pada hasil rekaman. Hasil perekaman disimpan dalam bentuk format ( ${ }^{*}$.wav).

\subsection{Metode FFT dan Spectral Analysis}

Perubahan sinyal yang terjadi dari sinyal audio asli yang berupa gelombang dalam domain waktu bertransformasi menjadi sinyal dalam domain frekuensi. Transformasi sinyal audio asli dapat dilihat pada Gambar 7.

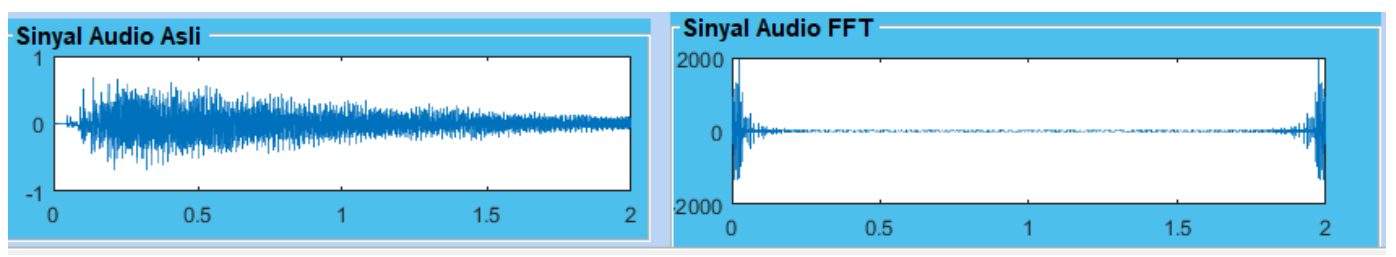

Gambar 7. Transformasi Metode FFT

Gambar 7 menjelaskan mengenai transformasi sinyal audio. Suara diubah ke bentuk gelombang spektrum suara yang berbasis frekuensi sehingga memudahkan proses analisis spektrum suara untuk dapat dilakukan analisis selanjutnya pada Spectral Analysis. Hasil Spectral Analysis dapat dilihat pada Table2.

Table2. Hasil Spectral Analysis

\begin{tabular}{ccccccc}
\hline & Chord & Cntroid & Kurtosis & Slope & Skewness & Rolloff \\
\hline $\mathbf{1}$ & $\mathrm{A}$ & $1.9772 \mathrm{e}+04$ & 279.0535 & $1.8208 \mathrm{e}-07$ & 12.9088 & $2.0510 \mathrm{e}+04$ \\
\hline $\mathbf{2}$ & $\mathrm{A}$ & $1.9781 \mathrm{e}+04$ & 277.8052 & $1.8208 \mathrm{e}-07$ & 12.8789 & $2.0532 \mathrm{e}+04$ \\
\hline $\mathbf{3}$ & $\mathrm{A}$ & $1.9960 \mathrm{e}+04$ & 330.4943 & $2.2544 \mathrm{e}-07$ & 15.4218 & $2.0494 \mathrm{e}+04$ \\
\hline $\mathbf{4}$ & $\mathrm{A}$ & $1.9524 \mathrm{e}+04$ & 199.1920 & $1.7519 \mathrm{e}-07$ & 11.5654 & $2.0241 \mathrm{e}+04$ \\
\hline $\mathbf{5}$ & $\mathrm{A}$ & $1.9773 \mathrm{e}+04$ & 275.5077 & $1.8114 \mathrm{e}-07$ & 12.8180 & $2.0521 \mathrm{e}+04$ \\
\hline $\mathbf{6}$ & $\mathrm{A}$ & $1.9960 \mathrm{e}+04$ & 330.4943 & $2.2544 \mathrm{e}-07$ & 15.4218 & $2.0494 \mathrm{e}+04$ \\
\hline $\mathbf{7}$ & $\mathrm{A}$ & $2.0577 \mathrm{e}+04$ & 290.8367 & $2.7158 \mathrm{e}-07$ & 13.4937 & $2.1296 \mathrm{e}+04$ \\
\hline $\mathbf{8}$ & $\mathrm{A}$ & $2.0245 \mathrm{e}+04$ & 170.9186 & $2.8599 \mathrm{e}-07$ & 10.6886 & $2.0774 \mathrm{e}+04$ \\
\hline $\mathbf{9}$ & $\mathrm{A}$ & $1.9768 \mathrm{e}+04$ & 280.0302 & $1.8208 \mathrm{e}-07$ & 12.9546 & $2.0510 \mathrm{e}+04$ \\
\hline$\ldots$ & $\ldots$ & $\ldots$ & $\ldots$ & $\ldots$ & $\ldots$ & $\ldots$ \\
\hline
\end{tabular}




$\begin{array}{lllllll}490 & G & 1.9771 \mathrm{e}+04 & 276.7279 & 1.5268 \mathrm{e}-07 & 13.2245 & 2.0650 \mathrm{e}+04\end{array}$

Proses pengenalan pada Table2 yaitu hasil Ekstraksi fitur Spectral Analysis. Spectral Analysis mengambil file suara yang telah diproses secara FFT sebelumnya sebanyak 490 chord yang terdiri dari masing-masing 70 chord kemudian di ekstraksi untuk mendapatkan lima nilai Spectral.

\subsection{Hasil Pengujian Sistem}

Pengambilan file data set training diperlukan sebelum melanjutkan ke tahap berikutnya yaitu proses pengenalan chord gitar menggunakan Metode K-Nearest Neighbor (K-NN). Proses pengenalan menggunakan metode K-NN memerlukan nilai input dari parameter k. Sistem mulai melakukan proses pengenalan dengan menyesuaikan nilai spectral feature data uji dengan nilai spectral feature yang terdapat pada data set training sebagai nilai variabel pengenalan. Proses pengenalan ini menghasilkan label dari kategori chord gitar. Pengujian pada parameter $\mathrm{k}$ dilakukan dengan mengubah parameter $\mathrm{k}$ dengan nilai yang telah ditentukan. Hasil pengujian sistem dapat dilihat pada Gambar 8, 9, 10, dan 11.

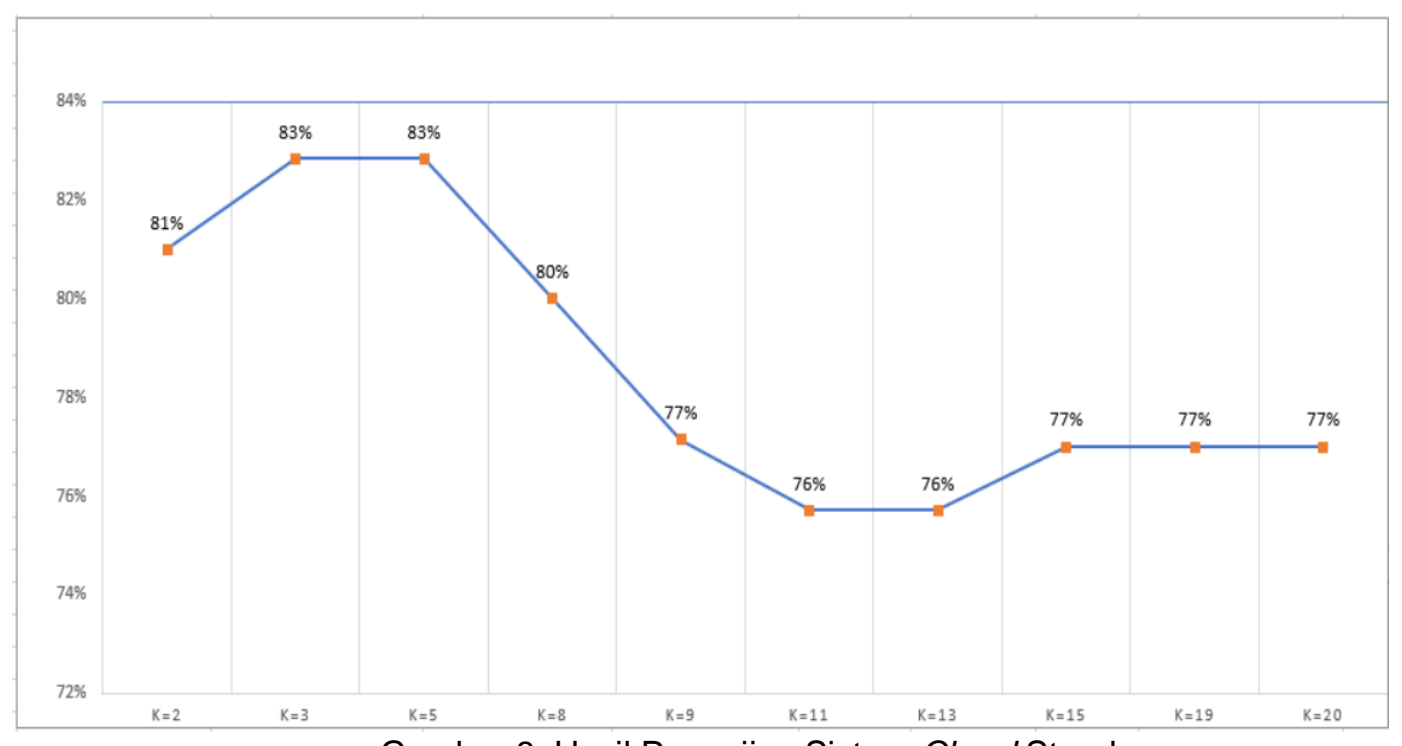

Gambar 8. Hasil Pengujian Sistem Chord Standar

Gambar 8 menjelaskan mengenai hasil pengujian sistem chord standar dengan nilai akurasi tertinggi yang dihasilkan adalah $83 \%$ dengan nilai parameter $k$ yaitu 3 dan 5 . Jadi jika dibandingkan 70 chord data uji dengan data hasil pengenalan Metode K-NN terdapat 58 data yang sama dan nilai akurasi terendah yang dihasilkan adalah $76 \%$ dengan nilai parameter $\mathrm{k}$ yaitu 11,13 sehingga terdapat 53 data yang sama. 


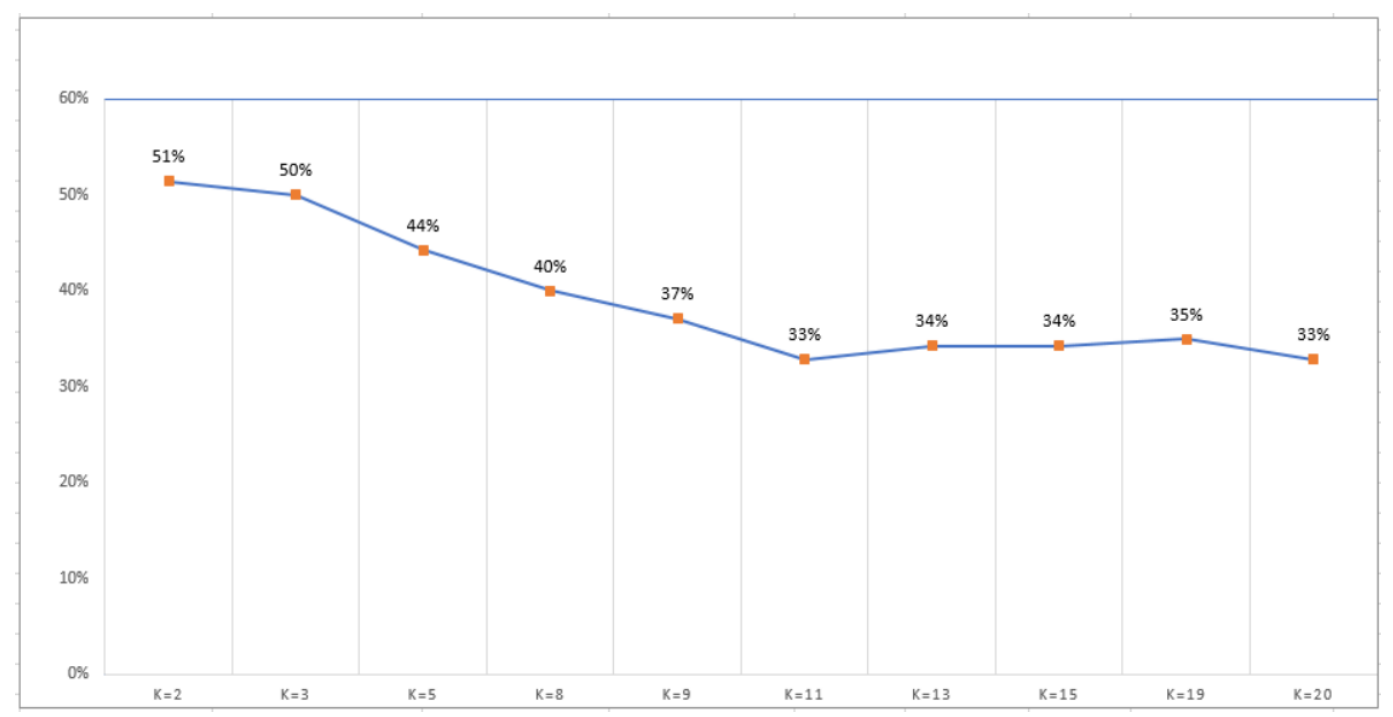

Gambar 9. Hasil Pengujian Sistem Chord Drop D

Gambar 9 menjelaskan mengenai hasil pengujian sistem chord drop D dengan nilai akurasi tertinggi yang dihasilkan adalah $51 \%$ dengan nilai parameter $\mathrm{k}$ yaitu 2 . Jadi jika dibandingkan 70 chord data uji dengan data hasil pengenalan Metode K-NN terdapat 36 data yang sama dan nilai akurasi terendah yang dihasilkan adalah $33 \%$ dengan nilai parameter $\mathrm{k}$ yaitu 11 dan 20 dengan 23 data yang sama.

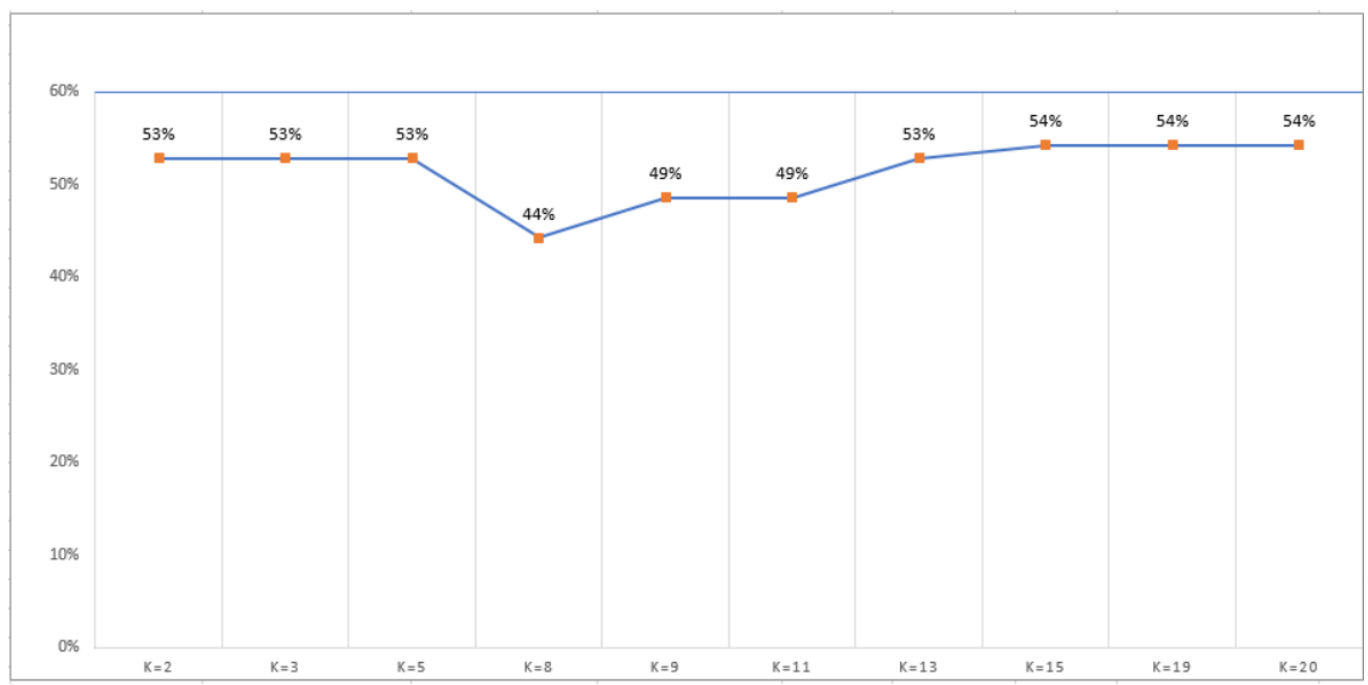

Gambar 10. Hasil Pengujian Sistem Chord Standar dengan Noise

Gambar 10 menjelaskan mengenai hasil pengujian sistem chord standar dengan noise dimana nilai akurasi tertinggi yang dihasilkan adalah $54 \%$ dengan nilai parameter k yaitu 15,19 , 20. Jadi jika dibandingkan 70 chord data uji dengan data hasil pengenalan Metode K-NN terdapat 37 data yang sama dan nilai akurasi terendah yang dihasilkan adalah $44 \%$ dengan nilai parameter $k$ yaitu 8 dengan 31 data yang sama. 


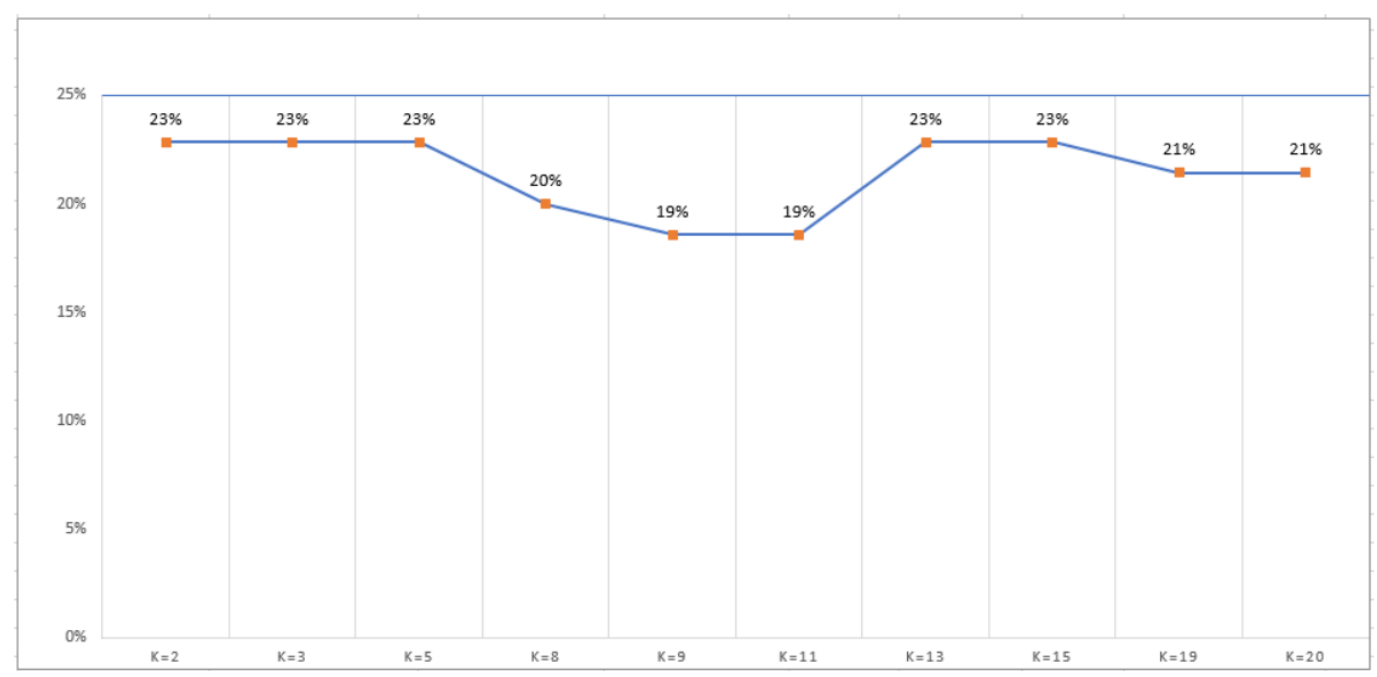

Gambar 11. Hasil Pengujian Sistem Chord Standar dengan Gitar Half Size

Gambar 11 menjelaskan mengenai hasil pengujian sistem chord standar dengan gitar half size dimana nilai akurasi tertinggi yang dihasilkan adalah $23 \%$ dengan nilai parameter $k$ yaitu $2,3,5,13,15$. Jadi jika dibandingkan 70 chord data uji dengan data hasil pengenalan Metode KNN terdapat 16 data yang sama dan nilai akurasi terendah yang dihasilkan adalah $19 \%$ dengan nilai parameter $\mathrm{k}$ yaitu 9,11 sehingga terdapat 13 data yang sama.

\subsection{Analisis Pengujian}

Data set chord standar cenderung memiliki tingkat akurasi yang tinggi, dikarenakan nilai fitur yang dihasilkan cendurung memiliki kedekatan dengan chord standar yang digunakan sebagai sampel data training, sedangkan pada data chord drop d, chord gitar dengan noise dan gitar half size menghasilkan nilai fitur yang cenderung berbeda dengan data yang digunakan sebagai training untuk setiap kategorinya, hal ini disebabkan karena perbedaan nilai fitur yang dihasilkan dari data uji dengan data traning. Nilai data uji yang seharusnya terklasifikasi atas suatu kategori dapat berbeda dengan nilai fitur katagori seharusnya karena data yang di uji cenderung berbeda ataupun memiliki noise. Noise dapat disebabkan oleh gangguan suara dari lingkungan, jack audio yang kurang rapat sambungannya dan bisa juga dari kesalahan bermain gitar. Chord standar dengan gitar half size menghasilkan nilai fitur yang cenderung berbeda dan memiliki tingkat akurasi lebih rendah hal itu disebabkan karena perbedaan panjang senar, tegangan senar, masa jenis senar, dan luas penampang senar yang berbeda ikut mempengaruhi nilai fitur. Parameter $\mathrm{k}$ pada metode K-NN juga mempengaruhi akurasi yang dihasilkan oleh sistem pengenalan. Data uji yang cenderung noise dapat memiliki kemiripan dengan data traning yang bukan katagori seharunya sehingga ketika menggunakan parameter $\mathrm{k}$ yang besar maka ada kemungkinan data training yang bukan katagori seharusnya masuk kedalam kumpulan tetangga terdekat dari data uji dan mempengaruhi hasil klasifikasi.

\section{Kesimpulan}

Penerapan metode Spectral Analysis sebagai metode ekstraksi fitur dan metode K-NN sebagai metode klasifikasi mampu digunakan untuk mengambil ciri dan mengklasifikasi suara pada chord gitar. Hasil pengujian sistem dengan chord standar, chord drop D, dan chord standar dengan gitar half size menampilkan tingkat akurasi yang berbeda-beda. Pengujian sistem dengan chord standar menghasilkan tingkat akurasi yang paling tinggi yaitu $83 \%$ dan pengujian sistem dengan gitar half size menghasilkan tingkat akurasi yang paling rendah yaitu $23 \%$. Perbedaan tingkat akurasi disebabkan karena adanya perbedaan nilai feature yang dihasilkan setiap data set yang di uji dengan sampel data training. Pemilihan atau penyaringan terhadap chord yang dimasukkan dapat mengurangi adanya sampel noise. Pemilihan data chord gitar mampu mempengaruhi performa dan akurasi metode K-NN saat melakukan klasifikasi pada chord gitar. 


\section{Daftar Pustaka}

[1] E. Trisnowati, "Analisis Frekuensi Pada Gong Laras Slendro," Indonesian Journal of Science and Education, vol. 1, no. 1, pp. 30-35, 2017.

[2] E. Wisnudisastra, A. Buono, "Pengenalan Chord pada Alat Musik Gitar Menggunakan CodeBook dengan Teknik Ekstraksi Ciri MFCC," Jurnal IImiah IImu Komputer, vol. 14, pp. 16-21, 2010.

[3] A. Eko, A. Syai, T. Hartati, “Teknik Dasar Bermain Gitar Elektrik di Sekolah Musik Prodigy Conservatory of Music di Kota Banda Aceh," Jurnal IImiah Mahasiswa Program Studi Pendidikan Seni Drama Tari dan Musik, vol. 1, no.1, pp. 1-10, 2016.

[4] Mustakim, G. Oktaviani, "Algoritma K-Nearest Neighbor Classification Sebagai Sistem Prediksi Predikat Prestasi Mahasiswa," Jurnal Sains, Teknologi dan Industri, vol. 13, no.2, pp. 195-202, 2016.

[5] Isnardi, "Monitoring Bus Trans Padang Berbasis Web," Jurnal J-Click, vol. 3, no. 2, 2016.

[6] I K. G. D. Putra, Pengolahan Citra Digital. Andi Yogyakarta, 2010.

[7] K. Muludi, Aristoteles, and A. F. Loupatty, "Chord Identification Using Pitch Class Profile Method with Fast Fourier Transform Feature Extraction," International Journal of Computer Science Issues, vol. 11, 2014.

[8] B. Eftekharnejad, M. R. Carrasco, B. Charnley, and D. Mba, "The application of spectral kurtosis on Acoustic Emission and Vibrations from a defective bearing," Mechanical System and Signal Processing, vol 25, pp 266-284, 2011.

[9] Stolar, Lech, and M. Allen, "Detection of Adolescent Depression from Speech Using Optimised Spectral Roll-Off Parameters," Biomedical Journal of Scientific and Technical Research, vol. 5, no. 1, pp. 1-10, 2014.

[10] W. Buana, S. Jannet, and I K. G. D. Putra "Combination of K-Nearest Neighbor and KMeans based on Term Re-weighting for Classify Indonesian News," International Journal of Computer Applications, vol. 50, pp. 37-42, 2012.

[11] V. Bijalwan, V. Kumar, P. Kumari, and J. Pascual, "KNN based Machine Learning Approach for Text and Document Mining," International Journal of Database Theory and Application, vol.7, pp.61-70, 2014.

[12] A. S. Devi, I. K. G. D. Putra, and I M. Sukarsa, "Implementasi Metode Clustering DBSCAN pada Proses Pengambilan Keputusan," Lontar Komputer Jurnal IImiah Teknologi Informasi, vol. 6, no.3, pp. 185-191, 2015.

[13] I D. A. A. Yunita Primandari, I K. G. D. Putra and I M. Sukarsa, "Customer Segmentation Using Particle Swarm Optimization and K-Means Algorithm," International Journal of Digital Content Technology and its Applications (JDCTA), vol 10, 2016.

[14] I K. G. D. Putra, P. A. Resmawan, "Verifikasi Biometrika Suara Menggunakan Metode MFCC Dan DTW," Lontar Komputer Jurnal Ilmiah Teknologi Informasi, vol. 02, no. 1, 2011. 